\title{
Impact of Liquidity Rules on Shareholders' Returns in Jordan Islamic Bank
}

\author{
Abdullah Ibrahim Nazal ${ }^{1} \&$ Fuad Al- Fasfus ${ }^{2}$ \\ ${ }^{1}$ Islamic Banking Department, Zarqa University, Jordan \\ 2 Accounting Department, Zarqa University, Jordan \\ Correspondence: Abdullah Ibrahim Nazal, Islamic Banking department; Zarqa University, Jordan. E-mail: \\ nazzalacademy@yahoo.com
}

Received: February 26, 2018

Accepted: May 3, 2018

Online Published: May 15, 2018

doi:10.5539/ijbm.v13n6p225

URL: https://doi.org/10.5539/ijbm.v13n6p225

\begin{abstract}
This paper aims to explore the impact of liquidity increases by local and international roles on shareholders' returns in the Jordan Islamic Bank as case study. The study methodology based on financial tables annual reports of the bank from (2009-2016) in order to analysis asset liquidity risk standard and its affection on managing balance sheet, and analysis returns for common shareholders in the Bank also discuss the result of shares return reducing. The real impact is deferent because the market price of the Jordan Islamic Bank shares is not affected negatively by the rule. Its price in the market is more than the share value by the ratio (all equities/ all shares). The percentage between the market price and ratio was equal to $202 \%$ in 2014 and reduced to $155 \%$ in 2016 . By discussion, the ratio there is a gap of equities impact as a result of applying depreciation on fixed assets yearly, regardless of its growth by market price. Fair result is to increase equities based on fixed assets market price increasing. This paper contributed to the knowledge by different ways, it helps leaders and managers to find the real impact of managing liquidity risk in the Islamic Bank by the Central Bank and Basel Committee.
\end{abstract}

Keywords: Shari'ha, accounting, liquidity, risk, shareholders' returns

\section{Introduction}

\subsection{Introduce the Problem}

Increasing liquidity will reduce investing amount and reduce profit of Islamic bank shareholders. There is a need to analysis this case in Jordan Islamic bank and explain it to shareholder also there is need to explain impact of liquidity rule controlling success. Jordan Islamic Bank shareholders and investment account customers need insurance to get Islamic services up to shari'ha which give profit to sharer without transfer current profit (Munusamy et al., 2010).

The model of search as follow:

\begin{tabular}{|c|c|}
\hline $\begin{array}{l}\text { Jordan Islamic bank Liquidity: } \\
\text { - } \quad \text { Reserves types rules } \\
\text { - } \quad \text { Financial market tools rules } \\
\text { - } \quad \text { Tax rules }\end{array}$ & $\begin{array}{ll}\text { Shareholders' Returns } \\
\text { - } & \begin{array}{l}\text { Increasing Distributed profit per } \\
\text { share }\end{array} \\
\text { - } & \text { Buy things with discount } \\
\text { - } & \text { Get new shares as return } \\
\text { - Increasing Share market price } \\
\text { - Increasing Distributed profit per } \\
\text { share }\end{array}$ \\
\hline
\end{tabular}

To study impact liquidity rules in Jordan Islamic bank case there are analysis of asset liquidity risk standard by 
show importance of current liquidity standard and its Impact on managing balance sheet, also liquidity controlling supervision on other hand there is need to analysis returns for common shareholders in Jordan Islamic Bank and discuss the result of shares return reducing.

Thus, the problem of this paper is to compare the real impact to the expected impact of reducing shareholders' returns in the Jordan Islamic Bank after applying the rule of the current assets increase and reserves in the Jordanian environment. Therefore, Jordan Islamic Bank's annual reports are used to analyze liquidity rules in financial statements. Expected impact showed that the Central Bank rule is responsible for the reduction of shareholders' returns as a result of applying reserves and reducing long term investing to face liquidity risk.

\subsection{Explore Importance of the Problem}

Transfer profit is part of liquidity rules which give common shares losing of getting currently returns. This will explain to shareholders the environment of Jordan Islamic bank to get trust between management and shareholders after facing reducing of returns.

\subsection{Describe Relevant Scholarship}

Last studies do not concentrate on current case of Jordan Islamic bank liquidity rules as case study. Rules must be measured and must give the objectives. Jarhi (2003) explained that Basel rules are not suitable for Islamic banks because there is a difference between Islamic banks and traditional banks. Frederick, (2011) Found that the Islamic Bank investing risk is less than traditional banks because traditional banks depend on speculations but Islamic banks depend on dealing with goods and services.

There are similar situations such as dealing with current accounts (deposits) like loans without giving interest rates to customers, as well as banking services such as transfers or currencies exchanges. There are different situations between Islamic banks and traditional banks due to investing accounts, (deposits) types and Shari'ha accounting. Therefore, there is a need for suitable rules.

Practically, the rule of balance sheets is calculated based on the accounting rule:

$$
\text { All assets }=\text { All liabilities }+ \text { Equities }
$$

Any rule will limit or impact any of the calculating rules such as impact assets,-liabilities or equities will impact of the result.

Hassan and Bushir, (2002) found that Islamic banks must have a big capital to get a suitable profit because its investments are direct investing, therefore, the standard of (capital/assets) ratio must be different than traditional banks.

Sadique, (2009) found that Islamic rules obligate the sharer in investing accounts services to share in loss based on sharer capital sharing, therefore, the standard of (assets/equities) ratio should not be the same as in traditional banks.

Shaikh. S, (2011) found that some Islamic banks' investing such as Modarabah can adjust equities by the sharer by working without capital. This effort has value and it can be a part of equity financing in Islamic banks.

These researchers explained the factors that cause different standards than traditional banks.

\section{Methodologies}

The study depends on finding reasons of increasing liquidity based on financial tables of Jordan Islamic bank and to find this liquidity impact on reducing shareholders' returns. It depends on analysis Jordan Islamic bank financial statements which were shown by the bank annual reports from $(2009-2016)$.

The study concentrates on analysis case of Jordan Islamic bank based on accounting data by Income statement and balance sheet, also data in Jordan financial market, and Jordan Islamic bank internet site. The study will use the historical analysis to compare impact between years.

\section{Banks Liquidity Rules}

Liquidity rule is applied by the Central Bank and Basel to face bank credit risk deficiency. Islamic banks ask for suitable rules because its work depends on producing, selling, sharing, lease and working. Elsiefy, (2013) explained the differences between Islamic banks and traditional banks based on financial ratios in liquidity and profitability. Atmeh and Abu Serdaneh (2012) also found that Islamic rules give accounting data different than international accounts. On the other hand, Ramadan, (1997) explained the importance of liquidity to buy liabilities at a suitable time. Therefore, liquidity is insurance trust for customer dealing with the bank. These 
results need to be balanced. Liquidity needs suitable standards in order to keep customer trust and to get suitable returns for shareholders.

Liquidity rules of the Central Bank and Basel direct assets to reduce long term investing or apply Sukuk to continue long term investing. Liquidity by reserves will cause a problem of reducing distributed return for investment account customers and shareholders. There is an expected problem that liquidity will be affected by inflation which reduces cash value and reduces shareholders' wealth value. In Jordan, the inflation rate equals $3.3 \%$ in 19/11/2017 according to the Jordan Central Bank website. It is close to the customer deposit interest that equals $3.75 \%$ in 19/11/2017 according to the Jordan Central Bank website. This means that interests are not useful in traditional banks for customer investing accounts. Islamic banks will give a profit close to this interest based on the Central Bank order. The problem of Gross Producing Domestic is less than deficient in Jordan. There was a reduction on industry because of taxes in spite of the need to build producing investments locally to reduce import.

These reasons make it challenging to get suitable Islamic bank returns because Islamic banks' success is measured by applying the liquidity rule. Shareholders' returns will be affected by liquidity environment in the country, see table 1:

Table 1. Liquidity rules factors and Shareholder returns factors in Islamic bank

\begin{tabular}{|c|c|c|c|c|c|}
\hline \multirow[t]{5}{*}{$\begin{array}{l}\text { Liquidity } \\
\text { environment } \\
\text { factors: }\end{array}$} & $\begin{array}{l}\text { 1- Current assets/ } \\
\text { current liabilities }\end{array}$ & 2-Reserves & $\begin{array}{l}\text { 3- Developing } \\
\text { liquidity tools }\end{array}$ & $\begin{array}{l}\text { 4-Percentage of Bank } \\
\text { service contract profit } \\
\text { instead if interest }\end{array}$ & 5- Tax \\
\hline & $\begin{array}{l}\text { Obligate to increase } \\
\text { current assets }\end{array}$ & $\begin{array}{l}\text { Voluntary } \\
\text { reserve }\end{array}$ & Sukuk & $\begin{array}{l}\text { Obligate low profit } \\
\text { percentage to investing } \\
\text { accounts customers as tool } \\
\text { to reduce collecting cash } \\
\text { from market }\end{array}$ & $\begin{array}{l}\text { Fees and stamps } \\
\text { of any contract }\end{array}$ \\
\hline & $\begin{array}{l}\text { Obligate to reduce } \\
\text { current liabilities }\end{array}$ & $\begin{array}{l}\text { Obligatory } \\
\text { reserve }\end{array}$ & $\begin{array}{l}\text { Close Investing } \\
\text { boxes }\end{array}$ & $\begin{array}{l}\text { Obligate high profit } \\
\text { percentage to investing } \\
\text { accounts customers as tool } \\
\text { to increase collecting cash } \\
\text { from market }\end{array}$ & Income tax \\
\hline & $\begin{array}{l}\text { Obligate to increase } \\
\text { current assets } \\
\text { percentage more }\end{array}$ & $\begin{array}{l}\text { Adjusted } \\
\text { profit } \\
\text { reserves }\end{array}$ & $\begin{array}{l}\text { Open Investing } \\
\text { boxes }\end{array}$ & $\begin{array}{l}\text { Sales in delay or } \\
\text { installments by Fixed } \\
\text { profit percentage }\end{array}$ & Customs tax \\
\hline & $\begin{array}{l}\text { than obligate to } \\
\text { reduce current } \\
\text { liabilities percentage }\end{array}$ & $\begin{array}{l}\text { Lose risk } \\
\text { reserve }\end{array}$ & $\begin{array}{l}\text { Islamic bonds } \\
\text { Deposit } \\
\text { certificate } \\
\text { Portfolio }\end{array}$ & $\begin{array}{l}\text { Sales in delay or } \\
\text { installments by changed } \\
\text { profit percentage as } \\
\text { (Jodibour percentage) }\end{array}$ & $\begin{array}{l}\text { Sales tax } \\
\text { Education and } \\
\text { universities tax } \\
\text { Tax on tax }\end{array}$ \\
\hline Shareholders & 1- Increasing & 2- $\quad$ Buy & 3- Get new & 4- Increasing Share & 5-Increasing \\
\hline Returns factors: & $\begin{array}{l}\text { Distributed profit } \\
\text { per share }\end{array}$ & $\begin{array}{l}\text { things with } \\
\text { discount }\end{array}$ & $\begin{array}{l}\text { shares } \\
\text { return }\end{array}$ & market price & $\begin{array}{l}\text { Distributed } \\
\text { profit per } \\
\text { share }\end{array}$ \\
\hline
\end{tabular}

Resource: By Authors.

Jordan Central Bank is responsible for facing increases of cash inflation to protect savings value, cost value, employments rates value, loans value and value of investing by currencies. Increasing bank reserves and taxes are ways to reduce cash from dealing in order to keep inflation suitable. It is a way to reduce cash from markets. 
The Cycle of savings, investing and financing will be successful in case the producing succeeds but in case producing fails there will be a problem of using cash which will cause unsuitable inflation.

\section{Jordan Islamic Bank Case Study}

Jordan Islamic Bank is work in Jordan. It has to follow the Jordan Central Bank rules. Some of these rules concentrate on liquidity of asset. Rules will limit asset amount, asset type, asset place, asset way of calculated, asset evaluation, asset estimated, asset impact, assets liquidity, assets profitability, asset insurance and assets sharing in developing. Balance sheets in Jordan Islamic bank must be accepted by the Central Bank. This acceptance will direct all assets by limitations as in table 2 .

Table 2. Rules of assets examples

\begin{tabular}{lll}
\hline Assets rules types & Rules of assets examples: & Assets Rules impacts \\
\hline Asset amount: & As the highest asset amount or the lowest & Assets rules will cause limitations \\
& asset amount from all assets & As types classified based on field of \\
Asset type & investing or type of time or type of contract \\
& As current asset or fixed asset \\
Asset place & As growth of asset price or get profit from \\
Asset way of calculated & selling asset, or get return from lease asset or \\
& get return from sharing in invest. \\
& As evaluate asst by market price or cost \\
Asset evaluation & price or the average between market price \\
& and cost. \\
Asset estimated & As estimate future return of asset selling or \\
& sharing or leasing \\
Asset impact & As increase the other assets value or make \\
& integration \\
assets Liquidity & Easy to get cash flow at suitable time or easy \\
& to be sold any time without lose. \\
Assets profitability & suitable return it suitable time \\
Assets insurance & To reduce risk there is insurance as insurance \\
assets sharing in developing & contract against risk. \\
& It invests in economic sector based on \\
& sharing in developing as education, transport \\
in order to reduce general budget deficient.
\end{tabular}

Resource: by Authors.

This limitation is a law. This law impacts standards of choosing asset. Practically these factors have negative impact and positive impact. It needs to be balanced based on managing risk. Law limits the factors of the measure risk standard by the Central Bank and Basel committee rules. Rules of liquidity will impact choosing asset and liability.

Current liquidity is ratio rule to face deficiency in the banks. Jordan Islamic Bank is affected by the Central Bank rules to keep inflation in suitable case. It has to balance between current assets and short term liabilities. It has to buy its liabilities at the suitable time.

Banks have three ways to buy liabilities in suitable time as follows:

1- It can own cash

2- It can get loans.

3- It can own assets that can be bought quickly without loss.

The problem comes when all banks prefer to use cash in investing in order to increase profit. Banks can face increasing demand to get a loan from the Central Bank or other banks. This may increase cost of loan or cause a problem to find a loan at suitable time. Also, the other way owns short term assets that can be bought quickly. This will increase supply when all banks try to sell their assets together. Buyers will ask for a reducing price and delay buying until the price is reduced. These problems will cause a delay in buying liabilities at the suitable 
time and cause loss of trust.

Basel committee rules are a way to protect savings and investing. It was developed to meet bank risk as liquidity, profitability, insurance and sharing in developing. These rules become international rules which affect banking sector credit classification. Bad classification will cause problems such as avoid dealing with investments or obligate to buy high return to be accepted in international markets. Also, bad classification banks will be asked to buy high interest when it tries to get a loan.

Jordan Islamic bank must not deal with loans with interest. It cannot get a loan from another bank or center bank without buy interest. This case limits ways which means getting a loan is difficult. It tries to solve this problem by getting a loan without interest from bank with an obligation to give this bank loan without interest. The loans must be the same in amounts and deposit time. It is called: "Qard Hasan Motabadel".

\section{Asset Liquidity Risk Standard}

Asset liquidity risk standard is ruled to face credit risk. This risk comes when the bank loses the ability to creditors' money at suitable time or has to apply more cost by getting an emergency loan in order to cover buying creditors' money.

Bank depends on liabilities to finance its assets. Customer's current account is loan by law. Bank can use it as credit and derive it to make increasing of cash. Banks will not share customer by credit return, therefore return of using current account and derivative credit will be just for the bank, but investing accounts will be shared in the returns. Sharing of investment is developed by many types as Sukuk. Table 3 shows the financial assets by investing accounting holders.

Table 3. Financial assets by investing accounting holders (millions)

\begin{tabular}{lll}
\hline Financial assets with market price & $\mathbf{2 0 1 5}$ & $\mathbf{2 0 1 6}$ \\
\hline Companies shares & 21.55 & 23.4 \\
Islamic Sukuk & 10 & 10.47 \\
Financial assets without market price & $\mathbf{2 0 1 5}$ & $\mathbf{2 0 1 6}$ \\
Companies shares & 2.36 & 2.36 \\
Islamic bank portfilio & 6.82 & 4.37 \\
Islamic Sukuk & 4.6 & 4.6 \\
Mokarada (Modarabah) bonds & 8.15 & 9.3 \\
\hline
\end{tabular}

Resource: Jordan Islamic bank annual report (2016, p. 122).

There is increasing of current assets by shares, portfolio, sukuk and bonds. There is Sukuk increasing as currently assets in 2016. Sukuk is a developed financial tool. It is classified a risk by Standards and Poor's as international company. See table 4.

Table 4. Current asset liquidity by Sukuk (millions)

\begin{tabular}{llll}
\hline Risk classification organization & total In 2016 & total In 2015 & Risk degree \\
\hline S\&P & 4.6 & 4.6 & A \\
S\&P & 10.47 & 10.47 & BB \\
S\&P & 37.76 & - & BB- \\
\hline
\end{tabular}

Resource: Jordan Islamic bank annual report, (2016, p. 161).

\subsection{Importance of Current Liquidity Standard}

Liabilities of the bank have loans as short term loan and long term loan. Banks gets loans with interest and sells it as loans by interest. It will get profit when the interest of getting loans is less than interest of selling loans. Banks have to buy these loans interest. In this case, interest is a way to reduce the bank income tax as a result to consider buying tax is expenses. This case comes when tax has to be bought from earning profit after interest in income statement.

Increasing of using liabilities will cause high profit than using equity. This will encourage bank to increase liabilities. The problem comes when the bank's deal with liabilities is more than its equities. In case of clearance, 
the bank, because of losing asset, there will be liabilities rights for customers to get their savings and investing.

Law of banking is: "shareholders are just responsible for losing based on the size of sharing in capital of the bank". This law will clear assets to liquidity and give customers saving and investing based on the calculate: (all asset clearance liquidity after reduce expenses of clearance / all liabilities). The problem comes when it equals less than (1) because shareholders will lose some money.

This case obligates bank to balance between using liability size and owning equity size to apply standard by ratio: (liabilities/ equities).

\subsection{Impact of Current Liquidity Standard on Managing Balance Sheet}

Rule of liquidity obligates to calculate increasing of ratio (current assets / current liabilities) until it become $100 \%$. This means when there is time of buying credit there must be cash to meet this buying in the same time and amount. The percentage means to make current assets equal current liabilities. This ratio has three ways as follows:

- To keep current liabilities fixed and increase current assets. This can be done by reducing fixed assets to increase current assets or to develop assets to be Sukuk or bonds as a way to get liquidity to sell it at any time. The other way is to increase finance current assets by increasing equities. This case can be done by increasing the capital, reserves, and undistributed profit. Concentrating on increasing equities by reserves and undistributed return will reduce sharer returns and investing customer return. By applying high tax on net profit as $35 \%-45 \%$ will reduce their return to be near the apply interest rate. This reduction of sharer returns and customer returns will be accepted by increasing reserves as a result to reduce interest rates by Central Bank rules.

- To keep current assets fixed and reduce current liabilities by turning it back to creditors and customers such as reduce current accounts. This way is not sensible; as it's a way to lose customers. The other way is to reduce current liabilities by increasing long term liabilities. Developing long term liabilities by bonds and Sukuk is a way to make liquidity easier to be sold any time.

- To reduce current liabilities partly and increase current assets partly until ratio of (current asset /current liabilities) $=100 \%$.

Practically, Applying ratio of (current asset/current liabilities) to be equal 100\% will need time. Controlling of bank obligate percentages as in table 5:

Table 5. Arrangement of applying ratio of (current asset /current liabilities) to be $100 \%$

\begin{tabular}{llllll}
\hline Ratio & 2015 & 2016 & 2017 & 2018 & 2019 \\
\hline (current asset/current liabilities) minimum require & $60 \%$ & $70 \%$ & $80 \%$ & $90 \%$ & $100 \%$ \\
\hline
\end{tabular}

Resource: Basel committee on banking supervision. Note: all dates are as of $1 /$ January.

\subsection{Discuss Asset Liquidity Risk Standard}

Central Bank and Basel committee rules assets liquidity by give cash $100 \%$ accept of risk, because it can give bank ability to buy liabilities at current time and in future also to buy late liabilities. These percentages direct banks to keep cash more than their needs to in order to reduce risk of assets because cash does not have risks.

Practically, this measurement is not accepted because cash is impacted by inflation and reducing of currency exchange rate to reduce its power of buying. Keeping cash means to reduce the chance for investments because it is a way to keep liquidity.

Keeping cash is not a sensible way. When there is a possibility to increase inflation, or reduce currency power of buying, there is a direction to buy things to protect wealth such as goods, land, buildings, and shares. These things will keep wealth from loss by inflation and reduce of currency power of buying.

Financial market is responsible to protect sharing dealing from tricks in order to keep a cycle between saving, investing, and financing a success. When there are tricks of in dealing with shares or share prices that have a fixed price or reduced in inflation in the case of losing currency power, there will be immigration of capitals or losing of savings.

On the other hand, possibility of owning cash by people will increase prices as a result to buying things regardless of its increasing price. This case comes when people think their saving in banks is a loss. The problem is: "how can Islamic banks encourage people to increase their savings when there are reducing of savings value 
by inflation and weakness of investing in order to keep capitals from immigration.

Locally, people in Jordan face power of losing local diner value because of tax. $1 \mathrm{JD}$ equals 1.15 Euro but tax in Jordan reduces power of buying as a result to applying tax on emergency goods. Everyone in Jordan feels that increasing of salary is not enough to get things as years ago. Everyone buys emergency goods, therefore, they buy tax.

The tax comes directly such as $16 \%$ on sales or $25 \%$ as customs tax or $11 \%-40 \%$ of income tax. Also, it comes indirectly such as applying fixed price like increasing the price of oil regardless of its reducing price around the world.

Central banks and Basel committee rules' assets obligate to make short term investing than long term investing as low risk. Also, it gives the investment that gives annuities return low risk than investing that delay return to bought once in future. This rule impacts asset to be current asset and avoid long term investing. It directs the bank to invest in shares speculation, Sukuk speculation and reduce direct investing in companies as owner of sharing. Also it directs Islamic banks to make investing by Sukuk in order to get profit in short term and transfer risk to Sukuk buyer. This standard supports asset liquidity risk standard because it will give short term return to cover needs of buying liabilities.

Practically, this direction will cause loss of long term investing in spite of expecting high return; therefore, return of investing will be low because of short term investing. Speculation is short term investing. Its risk depends on ignorance of information and fast dealing by computer which reduces ability of controlling. Speculation is short term investing but with risk. Short term investing is not always lower risk than long term investing risk.

\subsection{Liquidity Controlling Supervision in Jordan Islamic Bank}

Jordan Islamic bank depends on making high liquidity from first month to cover deficiency of the liquidity within the year, see tables $6,7,8,9,10$ and 11 as follow:

Table 6. Liquidity in Jordan Islamic bank 2011 (millions)

\begin{tabular}{|c|c|c|c|c|}
\hline Liquidity Factors & Less than month & $\begin{array}{l}\text { More than month } \\
\text { and less than } 3 \\
\text { months }\end{array}$ & $\begin{array}{l}\text { More than } 3 \text { months } \\
\text { and less than } 6 \text { months }\end{array}$ & $\begin{array}{l}\text { More than } 6 \text { months and } \\
\text { less than year }\end{array}$ \\
\hline Current Assets & 1470.670 & 69.251 & 104.445 & 230.851 \\
\hline Current Liabilities & 545.462 & 279.0 & 271.826 & 337,849 \\
\hline Current liquidity ratio & $\begin{array}{l}\text { Assets } \\
\text { cover current } \\
\text { asset in this } \\
\text { case(1) }\end{array}$ & $\begin{array}{l}\text { Assets will not cover } \\
\text { current asset in this } \\
\text { case (2). It will get } \\
\text { liquidity from the case } \\
\text { no(1) }\end{array}$ & $\begin{array}{l}\text { Assets will not cover } \\
\text { current asset in this } \\
\text { case (3). It will get } \\
\text { liquidity from the case } \\
\text { no(1) }\end{array}$ & $\begin{array}{l}\text { Assets will not cover } \\
\text { current asset in this case } \\
\text { (4). It will get liquidity } \\
\text { from the case no(1) }\end{array}$ \\
\hline
\end{tabular}

Resource: by Authors based Jordan Islamic Bank annual report, (2012, p. 157).

Table 7. Liquidity in Jordan Islamic bank 2012 (millions)

\begin{tabular}{|c|c|c|c|c|}
\hline Liquidity Factors & Less than month & $\begin{array}{l}\text { More than month } \\
\text { and less than } 3 \\
\text { months }\end{array}$ & $\begin{array}{l}\text { More than } 3 \text { months } \\
\text { and less than } 6 \text { months }\end{array}$ & $\begin{array}{l}\text { More than } 6 \text { months and } \\
\text { less than year }\end{array}$ \\
\hline Current Assets & 876.5 & 127.6 & 164.1 & 343.88 \\
\hline Current Liabilities & 530 & 295.26 & 290.756 & 367.378 \\
\hline Current liquidity ratio & $\begin{array}{l}\text { Assets } \\
\text { cover current } \\
\text { asset in this } \\
\text { case(1) }\end{array}$ & $\begin{array}{l}\text { Assets will not cover } \\
\text { current asset in this } \\
\text { case (2). It will get } \\
\text { liquidity from the case } \\
\text { no(1) }\end{array}$ & $\begin{array}{l}\text { Assets will not cover } \\
\text { current asset in this } \\
\text { case (3). It will get } \\
\text { liquidity from the case } \\
\text { no(1) }\end{array}$ & $\begin{array}{l}\text { Assets will not cover } \\
\text { current asset in this case } \\
\text { (4). It will get liquidity } \\
\text { from the case no(1) }\end{array}$ \\
\hline
\end{tabular}

Resource: by Authors based Jordan Islamic Bank annual report (2012, p. 157). 
Table 8. Liquidity in Jordan Islamic bank 2013 (millions)

\begin{tabular}{|c|c|c|c|c|}
\hline Liquidity Factors & Less than month & $\begin{array}{l}\text { More than month } \\
\text { and less than } 3 \text { months }\end{array}$ & $\begin{array}{l}\text { More than } 3 \text { months } \\
\text { and less than } 6 \text { months }\end{array}$ & $\begin{array}{l}\text { More than } 6 \text { months and } \\
\text { less than year }\end{array}$ \\
\hline Current Assets & 1132.6 & 129.76 & 221.44 & 364.1 \\
\hline Current Liabilities & 564.9 & 329.1 & 309.58 & 442 \\
\hline Current liquidity ratio & $\begin{array}{l}\text { Assets will } \\
\text { cover current } \\
\text { asset in this } \\
\text { case(1) }\end{array}$ & $\begin{array}{l}\text { Assets will not cover } \\
\text { current asset in this } \\
\text { case (2). It will get } \\
\text { liquidity from the case } \\
\text { no(1) }\end{array}$ & $\begin{array}{l}\text { Assets will not cover } \\
\text { current asset in this } \\
\text { case (3). It will get } \\
\text { liquidity from the case } \\
\text { no(1) }\end{array}$ & $\begin{array}{l}\text { Assets will not cover } \\
\text { current asset in this case } \\
\text { (4). It will get liquidity } \\
\text { from the case no(1) }\end{array}$ \\
\hline
\end{tabular}

Resource: by Authors based Jordan Islamic Bank annual report (2014, p. 169).

Table 9. Liquidity in Jordan Islamic bank 2014 (millions)

\begin{tabular}{|c|c|c|c|c|}
\hline Liquidity Factors & $\begin{array}{l}\text { Less than } \\
\text { month }\end{array}$ & $\begin{array}{l}\text { More than } \\
\text { month and less } \\
\text { than } 3 \text { months }\end{array}$ & $\begin{array}{l}\text { More than } 3 \text { months } \\
\text { and less than } 6 \text { months }\end{array}$ & $\begin{array}{l}\text { More than } 6 \text { months and } \\
\text { less than year }\end{array}$ \\
\hline Current Assets & 1302.6 & 139.38 & 248.2 & 357.19 \\
\hline Current Liabilities & 636.9 & 347 & 335.1 & 471.33 \\
\hline Current liquidity ratio & $\begin{array}{l}\text { Assets will } \\
\text { cover current } \\
\text { asset in this } \\
\text { case(1) }\end{array}$ & $\begin{array}{l}\text { Assets will not } \\
\text { cover current asset } \\
\text { in this case (2). It } \\
\text { will get liquidity } \\
\text { from the case } \\
\text { no(1) }\end{array}$ & $\begin{array}{l}\text { Assets will not cover } \\
\text { current asset in this } \\
\text { case (3). It will get } \\
\text { liquidity from the case } \\
\text { no(1) }\end{array}$ & $\begin{array}{l}\text { Assets will not cover } \\
\text { current asset in this case } \\
\text { (4). It will get liquidity } \\
\text { from the case no( } 1 \text { ) }\end{array}$ \\
\hline
\end{tabular}

Resource: by Authors based Jordan Islamic Bank annual report (2014, p. 169).

Table 10. Liquidity in Jordan Islamic bank 2015 (millions)

\begin{tabular}{|c|c|c|c|c|}
\hline Liquidity Factors & $\begin{array}{l}\text { Less than } \\
\text { month }\end{array}$ & $\begin{array}{l}\text { More than month and } \\
\text { less than } 3 \text { months }\end{array}$ & $\begin{array}{l}\text { More than } 3 \text { months } \\
\text { and less than } 6 \text { months }\end{array}$ & $\begin{array}{l}\text { More than } 6 \text { months } \\
\text { and less than year }\end{array}$ \\
\hline Current Assets & 1100.9 & 118.1 & 219.8 & 419.28 \\
\hline Current Liabilities & 685.323 & 373.727 & 356.6 & 404 \\
\hline Current liquidity ratio & $\begin{array}{l}\text { Assets will } \\
\text { cover current } \\
\text { asset in this } \\
\text { case(1) }\end{array}$ & $\begin{array}{l}\text { Assets will not cover } \\
\text { current asset in this } \\
\text { case (2). It will get } \\
\text { liquidity from the case } \\
\text { no(1) }\end{array}$ & $\begin{array}{l}\text { Assets will not cover } \\
\text { current asset in this } \\
\text { case (3). It will get } \\
\text { liquidity from the case } \\
\text { no(1) }\end{array}$ & $\begin{array}{l}\text { Assets will not cover } \\
\text { current asset in this } \\
\text { case(4). }\end{array}$ \\
\hline
\end{tabular}

Resource: by Authors based Jordan Islamic Bank annual report, (2016, p. 165).

Table 11. Liquidity in Jordan Islamic bank 2016 (millions)

\begin{tabular}{|c|c|c|c|c|}
\hline Liquidity Factors & Less than month & $\begin{array}{l}\text { More than month and less } \\
\text { than } 3 \text { months }\end{array}$ & $\begin{array}{l}\text { More than } 3 \text { months and } \\
\text { less than } 6 \text { months }\end{array}$ & $\begin{array}{l}\text { More than } 6 \text { months } \\
\text { and less than year }\end{array}$ \\
\hline Current Assets & 1311.57 & 179.8 & 184.26 & 449.63 \\
\hline Current Liabilities & 775.3 & 389 & 404.358 & 435 \\
\hline Current liquidity ratio & $\begin{array}{l}\text { Assets } \\
\text { cover current } \\
\text { asset in this } \\
\text { case(1) }\end{array}$ & $\begin{array}{l}\text { Assets will not cover current } \\
\text { asset in this case (2). It will } \\
\text { get liquidity from the case } \\
\text { no(1) }\end{array}$ & $\begin{array}{l}\text { Assets will not cover } \\
\text { current asset in this case } \\
\text { (3). It will get liquidity } \\
\text { from the case no( } 1 \text { ) }\end{array}$ & $\begin{array}{l}\text { Assets will cover } \\
\text { current asset in this } \\
\text { case (4). }\end{array}$ \\
\hline
\end{tabular}

Resource: by Authors based Jordan Islamic Bank annual report, (2016, p. 165).

The tables show that the Jordan Islamic bank faced problems of meeting same amount of current liabilities with same amount of current asset at time of buying liabilities. This case shows the problem of increasing current assets than current liabilities depending on the first month of every year. 


\section{Analysis Returns for Common Shareholders in Jordan Islamic Bank}

Returns are impacted by Shar'ha accepted rules. Hasan (2008) explained that interest rate gives traditional banks increasing profit than Islamic banks because it gets returns from financial leverage.

Islamic banks avoid returns from giving loans with interest therefore Jordan Islamic Bank can not get financial leverage. Financial leverage comes when operation profit reduced by interest such as reducing expenses then there will be given tax from profit after interest. In this case leverage will reduce tax.

There is a need to analyze returns in order to find impact of liquidity on shareholders return in Jordan Islamic bank. There are resources to get returns in Jordan Islamic Bank. The Fiqh Shari'ha accounting has different accounting than IFRS and government accounting rules in the figure1:

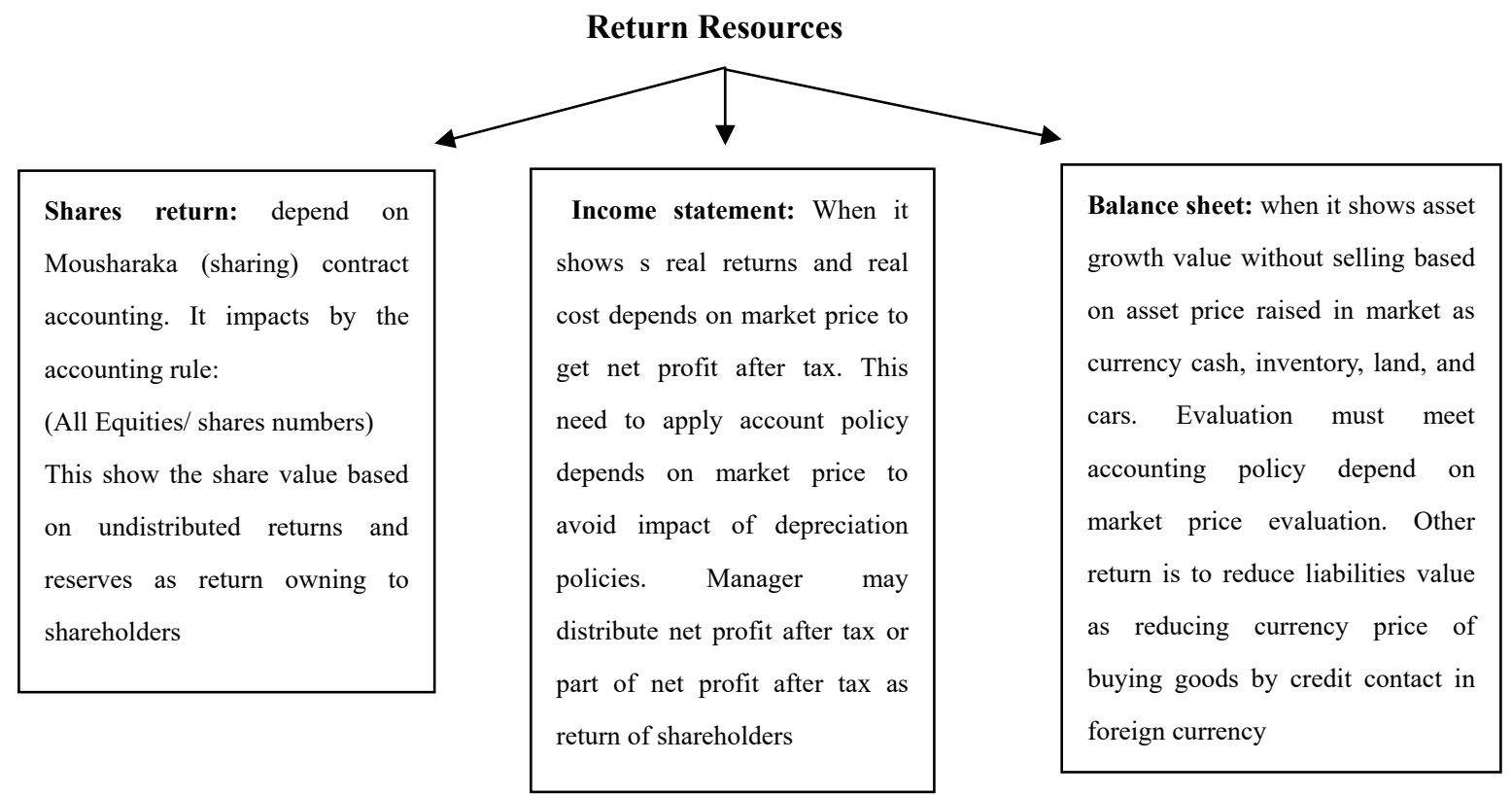

Figure 1. Return resources analysis based on Figh. Shari'ha accounting

Resource: by authors.

Figh Shari'ha accounting classified resource of returns based on assets service contract as work contract, sharing contract, selling contract and lease contract. Jordan Islamic bank works with its capital by these contracts to get all the contracts returns. It separates its investing by its capital and part of the current accounts services from its customer investing accounts by Modarabah. Jordan Islamic bank uses customer investing accounts as sharer by effort which called (Modarabah) and gets a part of profit after tax. Therefore, profit of the Jordan Islamic bank will equal (profit from using equities + profit from using part of current accounts + Part of profit from sharing with customers investing accounts + return from banking service as currency selling, transferring, accounts services).

\subsection{Shares Return Analysis in Jordan Islamic Bank}

To make comparing between Shares return theoretically by Shari'ha accounting and government account, there will be less return because of tax $35 \%-45 \%$ of net profit after tax added to reserves that equal $50 \%$ which lacks distribution of returns. Also, there are government fees. This impacts the shareholders' returns in Jordan Islamic bank negatively, see table 12 . 
Table 12. Shares return in Jordan Islamic bank

\begin{tabular}{|c|c|c|c|}
\hline Shares returns & 2014 & 2015 & 2016 \\
\hline Distributed return by law & 0.301 & 0.325 & 0.360 \\
\hline $\begin{array}{l}\text { Income tax of distributed return } \\
\text { by law }\end{array}$ & $\begin{array}{l}\text { Shareholder had to buy } \\
\text { income tax }=0.05 \text { which } \\
\text { make return reduced to be } \\
0,285 \mathrm{JD}\end{array}$ & $\begin{array}{l}\text { Shareholder had to buy } \\
\text { income tax }=0.05 \text { which } \\
\text { make return reduced to be } \\
0,308 \mathrm{JD}\end{array}$ & $\begin{array}{l}\text { Shareholder had to buy income } \\
\text { tax }=0.05 \text { which make return } \\
\text { reduced to be } 0,342 \mathrm{JD}\end{array}$ \\
\hline Market Share price in average & $3.8 \mathrm{JD}$ & $3.5 \mathrm{JD}$ & $3.55 \mathrm{JD}$ \\
\hline $\begin{array}{l}\text { Sellers of shares has to buy } \\
\text { commission * suppose it } \\
\text { equals: } 0.0034 \text { as commission } \\
\text { from share price in financial } \\
\text { market also seller s of shares } \\
\text { has to buy } 0.0034 \text { from the } \\
\text { share market price of selling }\end{array}$ & $\begin{array}{l}\text { Shareholders sellers had } \\
\text { Lost commission, therefore } \\
\text { the shareholders return of } \\
\text { selling is : } \\
3.8-(3.8 \times 0.0034)=3.78 \\
\text { JD }\end{array}$ & $\begin{array}{l}\text { Shareholders sellers had } \\
\text { Lost commission, therefore } \\
\text { the shareholders return of } \\
\text { selling is : } \\
3.5-(3.5 \times 0.0034)=3.48 \\
\text { JD }\end{array}$ & $\begin{array}{l}\text { Shareholders sellers had Lost } \\
\text { commission, therefore the } \\
\text { shareholders return of selling } \\
\text { is: } \\
\begin{array}{l}3.55-(3.55 \times 0.0034)=3.53 \\
1 \mathrm{JD}\end{array}\end{array}$ \\
\hline Equities/ shares numbers & $282212524 / 150000000$ & $311154659 / 150000000$ & $342719762 / 150000000$ \\
\hline & $=1.88 \mathrm{JD}$ per share & $=2.07 \mathrm{JD}$ per share & $=2.28 \mathrm{JD}$ per share \\
\hline $\begin{array}{lr}\text { Market Share price in } \\
\text { average/(Equities/ } & \text { shares } \\
\text { numbers) } & \end{array}$ & \multicolumn{3}{|c|}{$\begin{array}{l}\text { Reserves increase equities. There is increasing which will lead to reduce the different between } \\
\text { market price and the value of ratio that (equities/ share numbers). In } 2017 \text { Jordan Islamic bank } \\
\text { increase capital from } 150000000 \mathrm{JD} \text { to be } 180000000 \mathrm{JD} \text {. It was way to increase equities as way } \\
\text { to face the bank risk. }\end{array}$} \\
\hline
\end{tabular}

Resources: by Authors depending on Jordan Islamic bank Annual report 2016: 94 and in page 83 there was the Shari'ha Supervisory board report which accepts profit distributed. Jordan Islamic bank Annual report (2015: 90), https://www.ase.com.jo/ar/bulletins/yearly/new/2016-01-03.

*Amman Stock exchange market show details. There are different commissions based on the amount. Commission 3.4 per thousand for less than 100000 or it will increase until it reaches 7.5 per thousand. See: https://www.ase.com.jo/en/transaction-cost.

Practically, equities of the Jordan Islamic bank are adjusted to meet Central bank rules based on accounting policies. There will be choices such as evaluating depreciation and assets based on cost value, market value, and average between cost value and market value. This way it will not show the real return from asset and income statement net profit after tax. On the other hand, Share returns just depend on its part of distributed net profit after tax and its price in market based on share demands. This case will show return of selling shares when share market price becomes more than its share price cost. The table shows that share value by financial market is more than the result of the ratio: (Equities/ shares numbers). It is increasing $211 \%$ in 2014, increasing $169 \%$ in 2015 , and increasing $155 \%$ in 2016 . This means that financial market pricing shares is not measure the real price because of high demand on shares speculations.

\subsection{Discuss the Result of Shares Return in Jordan Islamic bank}

Equities in any bank are increased by the follow factors:

1 - Increase asset value as growth

2- Reduce liabilities value

3- Get undistributed net profit after tax and reserves

These factors must be accepted by Fiqh Shari'ha accounting. Shari'ha Supervisory Board is responsible to apply Shari'ha accounting in financial report. There a misunderstanding of depreciation rules on buildings every year. Accountants apply depreciation to reduce buildings value every year. This means assets lose value because of depreciation not by reducing buildings fair value that depend on market price. This Item will impact reducing equities negatively without Shari'ha accounting accepting. Fiqh Shari'ha accounting is shown in table 13: 
Table 13. Fiqh Shari'ha accounting rule of equities accounting

\begin{tabular}{|c|c|}
\hline \multirow{4}{*}{$\begin{array}{l}\text { Fiqh Shari'ha } \\
\text { accounting } \\
\text { ruled shares } \\
\text { value by the } \\
\text { ratio (Equities/ } \\
\text { shares } \\
\text { numbers). }\end{array}$} & $\begin{array}{l}\text { The Fiqh Shari'ha accounting of ratio must be adjusted of liabilities based on cost price except currencies. } \\
\text { Also, there is adjusted of asset value depend on market price except loans. There for accounting of al equities } \\
\text { will be equal: }\end{array}$ \\
\hline & $\begin{array}{l}\text { (All assets as loan must be fixed with out interest as cost price }+ \text { all assets that must be evaluated by market } \\
\text { price, as goods, lands, Currencies, financial notes, cars, buildings, furniture, machines, and equipment) } \\
\text { (minus -) }\end{array}$ \\
\hline & $\begin{array}{l}\text { All liabilities as loan or delay buying cash based on sales contract, sharing contracts, lease contract, and } \\
\text { working contracts must be fixed with out interest as cost price }+ \text { All Foreign currencies based on market price } \\
\text { value) }\end{array}$ \\
\hline & กII \\
\hline
\end{tabular}

Resource: by Authors.

Fiqh Shari'ha accounting depends on the market price of asset evaluations but the Jordan Islamic bank accounting is based on cost price with yearly reducing by depreciation. See table 14:

Table 14. Depreciation of fixed assets (millions)

\begin{tabular}{ll}
\hline Years & Depreciation of fixed assets yearly \\
\hline 2016 & 6.87 \\
2015 & 6.67 \\
2014 & 4.25 \\
2013 & 3.87 \\
2012 & 3.32 \\
2011 & 3.06 \\
2010 & 2.80 \\
2009 & 2.19 \\
\hline
\end{tabular}

Resources: by Authors based Jordan Islamic Bank annual reports, (2016: 126, 2014:127-128, 2012:119, 2010: 119).

Depreciation of fixed assets included land, building, equipments, machine, computers, furniture, transport means: the depreciation every year $=$ Cost price $\times$ Percentage of reducing

Accounting of fixed assets is shown in balance sheets by depreciation yearly not by fair value based on market price. This is a gap that reduces equities and the real value. Value of land and buildings in Jordan is increased by market price which is the best way to avoid inflation risk. Badwin, et.al, (2005) said that depreciation is a way to reduce tax because it shows more expenses. Depreciation helps to study investment behavior when tax accepts depreciation as expenses. Fang, et.al, (2005) explained applying depreciation on currencies as other assets. They explained currency depreciation by reduced currency value in floating exchange system. This means all assets can be applied by depreciations.

Atma. M and Alzabi. Z, (2014) found problem of discloser because standards of international financial reports follow Principles - based more than rules- based which leads to apply the manager rules on accounting data.

This means that managers will choose the suitable rule based on its aim when there is choosing standards by law.

Shari'ha accounting depends on evaluation by market price to give fair value to assets but accepted depreciation by law is increasing expenses to reduce cost in order to reduce tax. This conflicts Shari'ha accounting fairing and reduces tax that will reduce value of the Jordan Islamic bank financial tables to users. It may obligate to make two different types of financial tables based on accounting types. There will be financial tables based on Shari'ha accounting and other types of financial tables that will be based on Law accounting. Macintosh and Quattrone (2010) explained that ignorance happens by unclear depreciation installments and environment changing as restructure investing, restructure financing, and restructure managing structure.

\section{Conclusions}

Result 1: Managing of Jordan Islamic bank by Central banks and Basel committee rules are concentrating on 
protecting savings. This protection becomes reserves which cover more than $50 \%$ of net profit after tax.

Result 2: expected impact of increasing liquidity rule will be affected by inflation and losing currency power of buying. This affection will lose savings value, and reserves value. When Jordan Islamic bank gets in the highest level of liquidity, it will be at a high lose of saving value and will reserves in case of inflation or reducing currency power of buying. Also high reserves will reduce bank investing services marketing because of weak return unless it will meet investing accounts interest in traditional banks. Increasing current assets will reduce amount of long term investing which reduce profit and direct current assets to increase Sukuk and speculation. Reduce of shareholders return will increase supply of selling shares and reduce its price. Shareholders will loose in two ways, first: loose part of distributed return yearly, second: loose shares price.

Result 3: Jordan Islamic bank depends on owning the highest liquidity from the first month from 2014-2016 by increasing current asset in order to meet current liabilities with out deficiency.

Result 4: there is a difference between expected impact and the real impact. Expected impact showed that the Central bank rule will impact shareholders returns negatively but the real impact is showed by the market price of Jordan Islamic Bank shares. Its price in the market is more than the share value by the ratio (all equities/ all shares). The percentage between Market price and ratio of (all equities/ al shares) was equaled to $155 \%$ in 2016.

Result 5: there is gap of Shari'ha accounting that reduces fixed assets fair value which reduces equities.

\section{References}

Atmeh, M. A., \& Abu-Serdaneh, J. A. R. (2012). A proposed model for accounting treatment of Ijarah. International Journal of Business and Management, 7(18), 49. https://doi.org/10.5539/ijbm.v7n18p49

Atmeh, M., \& Alzabi, Z. (2014). The role of the audit profession in strengthening oversight and anti-corruption. Proceedings from Tenth International Scientific Conference Professional. Amman, Jordan.

Baldwin, J., Gellatly, G., Tanguay, M., \& Patry, A. (2005, October). Estimating depreciation rates for the productivity accounts. OECD Workshop on Productivity Measurement, Madrid Spain, October (pp. 17-19).

Elsiefy, E. (2013). Comparative analysis of Qatari Islamic banks performance versus conventional banks before, during and after the financial crisis. International Journal of Business and Commerce, 3(3), 11-41.

Fang, W., Lai, Y., \& Miller, S. M. (2006). Export promotion through exchange rate changes: Exchange rate depreciation or stabilization? Southern Economic Journal, 611-626.

Hasan, Z. (2010). Islamic Banks: Profit Sharing Equity and Credit Control.

Hassan, M. K., \& Bashir, A. H. M. (2003, December). Determinants of Islamic banking profitability. 10th ERF annual conference.

Jarhi, M. (2003). Monetary policy in the Islamic framework. Islamic Economic Studies. 9(1\&2), 62.

\begin{tabular}{|c|c|c|c|c|c|c|c|}
\hline \multicolumn{8}{|c|}{ http://www.cbj.gov.jo/Pages/viewpage.aspx?pageID=115 } \\
\hline \multicolumn{7}{|c|}{ http://www.cbj.gov.jo/Pages/viewpage.aspx?pageID=90 } & from \\
\hline \multicolumn{7}{|c|}{ http://www.jordanislamicbank.com/sites/default/files/Report2010.pdf } & from \\
\hline \multicolumn{8}{|c|}{ http://www.jordanislamicbank.com/sites/default/files/anuual\%202012.pdf } \\
\hline \multicolumn{7}{|c|}{ http://www.jordanislamicbank.com/sites/default/files/anuual.pdf } & from \\
\hline \multicolumn{8}{|c|}{ http://www.jordanislamicbank.com/sites/default/files/report2015s2.pdf } \\
\hline $\begin{array}{r}\text { Jordan } \\
\mathrm{htt}\end{array}$ & $\begin{array}{l}\text { Islamic } \\
\text { w.jordan }\end{array}$ & $\begin{array}{l}\text { Bank } \\
\text { icbank.com }\end{array}$ & $\begin{array}{l}\text { Annual } \\
\text { tes/default/f }\end{array}$ & $\begin{array}{l}\text { Report. } \\
\text { IB_Annuall }\end{array}$ & $\begin{array}{l}(2016) \text {. } \\
\text { ort_2016__ }\end{array}$ & $\begin{array}{l}\text { Retrieved } \\
\text { LOW.pdf } 3\end{array}$ & $\begin{array}{l}\text { from } \\
2017\end{array}$ \\
\hline
\end{tabular}


Munusamy, J., Chelliah, S., \& Mun, H. W. (2010). Service quality delivery and its impact on customer satisfaction in the banking sector in Malaysia. International Journal of Innovation, Management and Technology, 1(4), 398.

Perry, F. V., \& Rehman, S. S. (2011). Globalization of Islamic finance: Myth or reality. International Journal of Humanities and Social Science, 1(19), 107-119.

Sadique, M. (2009). Profit and loss allocation among Islamic bank and client partner in equity financing: Practice, precepts and alternatives.

Shaikh, S. A. (2011). A critical analysis of Mudarabah \& a new approach to equity financing in Islamic finance.

\section{Copyrights}

Copyright for this article is retained by the author(s), with first publication rights granted to the journal.

This is an open-access article distributed under the terms and conditions of the Creative Commons Attribution license (http://creativecommons.org/licenses/by/4.0/). 